\title{
Role of bilastine in allergic rhinitis: a review
}

Rachna Dhingra*

Department of ENT, G.G.S. Medical College, Faridkot, Punjab, India

Received: 14 November 2019

Accepted: 03 January 2020

\section{*Correspondence:}

Dr. Rachna Dhingra,

E-mail: rachnadhingra068@gmail.com

Copyright: (C) the author(s), publisher and licensee Medip Academy. This is an open-access article distributed under the terms of the Creative Commons Attribution Non-Commercial License, which permits unrestricted non-commercial use, distribution, and reproduction in any medium, provided the original work is properly cited.

\begin{abstract}
The prevalence of allergic diseases is increasing globally, most particularly in middle to low-income countries. Allergic rhinitis and urticaria are common allergic diseases that may have a major negative impact on patient's quality of life. Bilastine, a novel new-generation antihistamine that is highly selective for the H1 histamine receptor, has a rapid onset and prolonged duration of action. In the fasting state bilastine is quickly absorbed, but the absorption is slowed when it is taken with food or fruit juice. Therefore, it is recommended that bilastine is taken at least one hour before and no sooner than two hours after a meal. This review article describes about the role of bilastine in allergic reactions.
\end{abstract}

Keywords: Allergic rhinitis, Histamine, Bilastine

\section{INTRODUCTION}

Allergic diseases comprise a variety of conditions including allergic rhinitis, allergic asthma, atopic dermatitis, contact allergies, and food allergies. Urticaria can also occur either as an allergic or nonallergic response. The global prevalence of allergic diseases is up to $30 \%{ }^{1}$ Allergic rhinitis (AR) is classified as "intermittent" (symptoms for $<4$ days a week), "persistent" (symptoms present for $>4$ days a week and for more than 4 consecutive weeks), "mild", and "moderate" according to the allergic rhinitis and its impact on asthma (ARIA) guideline. ${ }^{2}$ Bilastine is a newer second-generation $\mathrm{H} 1$-antihistamine approved for the symptomatic treatment of AR and chronic urticaria (CU) in patients older than 12 years of age. AR and urticaria respond to antihistamine treatment and current international guidelines recommend nonsedating secondgeneration antihistamines as first-line treatment for both. ${ }^{3-5}$ Bilastine, or 2-[4-(2-(4-(1-(2-ethoxyethyl)-1Hbenzimidazole- 2-yl) piperidine-1-yl) ethyl) phenyl]-2methyl propionic acid, is a new next-generation antihistamine. ${ }^{6}$ It is a new piperidine molecule and belongs to the same chemical group as many new antihistamines (ebastine, fexofenadine, loratadine, desloratadine, rupatadine, levocabastine, emedastine, and epinastine). Within this group, it is chemically close to the piperidine-benzimidazole subgroup, which also includes molecules such as norastemizole and mizolastine.

\section{ABSORPTION, HALF LIFE PERIOD AND ROUTE OF ELIMINATION OF BILASTINE}

Bilastine does not undergo presystemic hepatic metabolism and has no active metabolites. It does not interact with the cytochrome $\mathrm{P} 450$ system and consequently is unlikely to be involved in drug-drug interactions. Like many other antihistamines, plasma levels of bilastine are increased by the concomitant administration of erythromycin, ketoconazole, or diltiazem, all inhibitors of P-glycoprotein (P-gp), and/or organic anion-transporting polypeptide (OATP) modulators of intestinal absorption. ${ }^{6}$ The half-life for bilastine $\left(t_{1 / 2}\right)$ is estimated at $14.53 \mathrm{~h}$, similar to that of fexofenadine and intermediate between published values 
for cetirizine or levocetirizine ( 8 to $10 \mathrm{hrs}$ ) and desloratadine $(26.8 \mathrm{hrs})$. These data in healthy volunteers indicate that a once-daily dose of bilastine $20 \mathrm{mg}$ maintains a sufficient plasma level to maintain its therapeutic activity for $24 \mathrm{hrs} .{ }^{6}$ Bilastine is mainly excreted in the feces $(66.5 \%)$ with some excreted in the urine $(28.3 \%)$. Nearly, all is excreted as the parent compound. Bilastine has a total clearance is $9.20 \mathrm{~L} / \mathrm{h}$ and a renal clearance of $8.7 \mathrm{~L} / \mathrm{h} .^{6}$

\section{ALLERGIC RHINITIS}

Allergic rhinitis is a symptomatic condition of the nose caused by allergen exposure and IgE-mediated inflammation. ${ }^{8}$ Allergic rhinitis is defined as intermittent or persistent, and its severity is classed as mild or moderate-to-severe. ${ }^{8}$ Patients with allergic rhinitis experience the three cardinal symptoms of sneezing, nasal obstruction, and rhinorrhea as a result of $\mathrm{IgE}$ mediated inflammation of the nasal mucosa. ${ }^{9}$ In addition, patients with allergic rhinitis can experience troublesome nonnasal symptoms, such as headache, thirst, and difficulty sleeping, as well as cough, snoring, wheezing, sinus pressure, sore throat, and ocular symptoms such as itchy, red or watery eyes. ${ }^{10-12}$

\section{BILASTINE EFFICACY IN TREATMENT OF RHINITIS}

In two multicenter, randomized, double-blind, placebo controlled trials in a total of 1,402 patients with seasonal allergic rhinitis, the efficacy of bilastine was compared with that of cetirizine and desloratadine. ${ }^{13,14}$ In one trial, over a 2-week treatment period, bilastine and cetirizine displayed similar efficacy: both compounds significantly reduced total symptom score relative to placebo. ${ }^{13}$

In a Vienna challenge chamber study performed outside the pollen season in 75 individuals with asymptomatic seasonal allergic rhinitis, an antihistamine or placebo was administered immediately before allergen challenge. ${ }^{15}$ The three antihistamines tested, bilastine, cetirizine, and fexofenadine, were all significantly effective ( $p$ value 0.001 ) regarding percentage mean decrease in total NSS versus placebo at all time points, including early (1 to 4 hrs) and late (22 to $26 \mathrm{hrs}$ ) after dosing. ${ }^{15}$ However, at the later time point, bilastine ( $\mathrm{p}$ value 0.0012 ) and cetirizine ( $p$ value 0.001 ) were both significantly more effective than fexofenadine. ${ }^{13}$

A randomized, double-blind, placebo-controlled trial, conducted in Europe, Argentina, and South Africa, compared the efficacy of bilastine with that of cetirizine and placebo over 4 weeks in 651 patients with perennial allergic rhinitis; in an open-label, extension phase, 513 patients were treated with bilastine $20 \mathrm{mg}$ once daily for 12 months, the longest analysis to date with any antihistamine. There was no statistically significant difference between groups. ${ }^{16}$ However, there was a region-specific effect: primary efficacy was significantly better in the antihistamine versus placebo groups in Europe and Argentina ( $\mathrm{p}$ value 0.039). Conversely, no significant difference was evident in South Africa, where patients reported a relatively high placebo response rate. ${ }^{16}$

\section{SAFETY, DOSAGE AND ADVERSE EFFECTS}

All clinical studies have demonstrated the safety and tolerability of bilastine with no statistically significant differences between the therapeutic dose $(20 \mathrm{mg})$ and placebo. ${ }^{7}$ The recommended dose of bilastine is $20 \mathrm{mg}$ in single daily dose, best taken at least $1 \mathrm{hr}$ before or $2 \mathrm{hr}$ after the intake of food or fruit juice. ${ }^{7}$ Headache, drowsiness, dizziness, and fatigue are the most common adverse events reported by patients with an incidence similar to placebo. ${ }^{17}$

\section{CONCLUSION}

Bilastine is a new-generation, nonsedating $\mathrm{H} 1$ antihistamine of piperidine family. Bilastine is efficacious in all nasal symptoms including obstruction and in eye symptoms in patients with allergic rhinoconjunctivitis. Bilastine is well tolerated. In the fasting state bilastine is quickly absorbed, but the absorption is slowed when it is taken with food or fruit juice. Therefore, it is recommended that bilastine is taken at least one hour before and no sooner than two hours after a meal.

\section{Funding: No funding sources \\ Conflict of interest: None declared \\ Ethical approval: Not required}

\section{REFERENCES}

1. Pawankar R, Canonica GW, Holgate ST, Lockey BS, Blaiss WS. World Allergy Association (WAO) White Book on Allergy. United States: World Allergy Organization; 2013.

2. Bousquet J, Van CP, Khaltaev N. Allergic rhinitis and its impact on asthma. J Allergy Clin Immunol. 2001;108:147-334.

3. Zuberbier T, Aberer W, Asero R, Abdul Latiff AH, Baker D, Ballmer-Weber B, et al. The EAACI/GA2LEN/EDF/WAO guideline for the definition, classification, diagnosis and management of urticaria. The 2017 revision and update. Allergy. 2018;73:1393-414.

4. Bousquet J, Khaltaev N, Cruz AA, Denburg J, Fokkens WJ, Togias A, et al. Allergic rhinitis and its impact on asthma (ARIA) 2008 update (in collaboration with the world health organization, GA (2) LEN and allerGen). Allergy. 2008;63(86):8160 .

5. Meltzer EO, Bukstein DA. The economic impact of allergic rhinitis and current guidelines for treatment. Ann Allergy Asthma Immunol. 2011;106:12-6.

6. Bilastine. Available at: https://www.pubchem.ncbi. nlm.nih.gov/compound/Bilastine. Accessed on 3 June 2019. 
7. Product Monograph Including Patient Medication Information. Blexten ${ }^{\circledR}$. Available at: https://www. aralez.com/wp-content/uploads/2016/12/

BLEXTEN-Product-Monography-English.pdf.

Accessed on 3 June 2019.

8. Bousquet J, Khaltaev N, Cruz AA, Denburg J, Fokkens WJ, Togias A, et al. Allergic Rhinitis and its Impact on Asthma (ARIA) 2008 update (in collaboration with the World Health Organization, GA(2)LEN and AllerGen). Allergy. 2008;63(86):8160

9. Pawankar R, Bunnag C, Khaltaev N, Bousquet J. Allergic rhinitis and its impact on asthma in Asia Pacific and the ARIA update 2008. World Allergy Organ J. 2012;5(3):212-7.

10. Leynaert B, Neukirch C, Liard R, Bousquet J, Neukirch F. Quality of life in allergic rhinitis and asthma. A population-based study of young adults. Am J Respir Crit Care Med. 2000;162(4):1391-6.

11. Meltzer EO, Blaiss MS, Naclerio RM, Stoloff SW, Derebery MJ, Nelson HS, et al. Burden of allergic rhinitis: allergies in America, Latin America, and Asia-Pacific adult surveys. Allergy Asthma Proc. 2012;33(1):113-41.

12. Canonica GW, Bousquet J, Mullol J, Scadding GK, Virchow JC. A survey of the burden of allergic rhinitis in Europe. Allergy. 2007;62(85):17-25.

13. Kuna P, Bachert C, Nowacki Z, van Cauwenberge P, Agache I, Fouquert L, et al. Efficacy and safety of bilastine $20 \mathrm{mg}$ compared with cetirizine $10 \mathrm{mg}$ and placebo for the symptomatic treatment of seasonal allergic rhinitis: a randomized, doubleblind, parallel-group study. Clin Exp Allergy. 2009;39:1338-47.

14. Bachert C, Kuna P, Sanquer F, Ivan P, Dimitrov V, Gorina MM, et al. Bilastine International Working Group. Comparison of the efficacy and safety of bilastine $20 \mathrm{mg}$ vs desloratadine $5 \mathrm{mg}$ in seasonal allergic rhinitis patients. Allergy. 2009;64:158-65.

15. Horak F, Zieglmayer P, Zieglmayer R, Lemell P. The effects of bilastine compared with cetirizine, fexofenadine, and placebo on allergeninduced nasal and ocular symptoms in patients exposed to aeroallergen in the Vienna Challenge Chamber. Inflamm Res. 2010;59:391-8.

16. Sastre J, Mullol J, Valero A; Bilastine Study Group. Efficacy and safety of bilastine $20 \mathrm{mg}$ compared with cetirizine $10 \mathrm{mg}$ and placebo in the treatment of perennial allergic rhinitis. Curr Med Res Opin. 2012;28:121-30.

17. Ridolo E, Montagni M, Bonzano L, Incorvaia C, Canonica GW. Bilastine: New insight into antihistamine treatment. Clin Mol Allergy. 2015;13:1

Cite this article as: Dhingra R. Role of bilastine in allergic rhinitis: a review. Int J Otorhinolaryngol Head Neck Surg 2020;6:431-3. 